\title{
How can Common Rational Capacities Confirm the Correctness of the Deduction in Groundwork III-and Why does it Matter?
}

\author{
Martin Sticker
}

\begin{abstract}
Kant claims in Groundwork IV:454 that the correctness of his complex philosophical deduction is confirmed by the 'practical use of common human reason'. My paper discusses how this confirmation is possible, and why it is important for Kant's project in the Groundwork. I argue that agents without philosophical training consider an intelligible standpoint, which is one of the central elements of the deduction, to be possible (i), that they take up this standpoint insofar as they reason under the idea of freedom (ii), and that they can be brought to acknowledge the higher normative authority of this standpoint (iii). Kant's complex deduction is not alien to common agents insofar as it spells out these three elements of our ordinary understanding of metaphysics, agency, and morality. I conclude that the confirmation of the deduction by common human reason shows that even the content of Groundwork III can become popular, and can serve to inform and direct moral education and moral improvement.
\end{abstract}

Kant claims that the practical use of common human reason 'confirms' [bestätigt] (IV:454.20) the correctness of his Groundwork III deduction. This paper discusses how common human reason can confirm the correctness of the deduction, which is, after all, a complex philosophical operation that goes beyond the ordinary agent's understanding, and what this conformation contributes to Kant's philosophical operation. The aim of my paper is neither to provide a new reading of Kant's entire Groundwork. III deduction, nor to critically assess the deduction's merits and weaknesses, but merely to understand the role our ordinary perspective or common rational capacities play for the deduction.

Even though common rational capacities feature prominently in Kant's major writings, they have only recently received the attention they deserve. ${ }^{1}$ In what follows, 'common rational capacities' denotes something which Kant 


\section{Martin Sticker}

refers to with different names, the most prominent being 'common (human) reason', 'common (human) understanding', 'natural/sound (human) understanding/ reason'. Something is 'common' if it is widely (or universally) shared among members of a group, and if it is not conditioned on certain privileges, outstanding cognitive capacities, philosophical insight or a special education. ${ }^{2}$ I will call a 'common agent' someone who is endowed with common rational capacities and who did not receive any special philosophical training, or academic education. Common rational capacities are the degree to which a rational human agent can make use of her reason without any special or philosophical education.

In the first section of this paper, I will provide a brief overview of Kant's conception of common rational capacities, and elaborate on the common agent's understanding of morality, which Kant seeks to clarify, systematize, and vindicate in his practical philosophy. In the second section, I will discuss the role of common rational capacities for the deduction. Finally, in the third section, I will discuss why Kant thought it important to have common rational capacities on the side of his deduction.

\section{Common Rational Capacities}

The aim of Kant's practical philosophy is not to construe a moral philosophy from scratch, but to make intelligible and to vindicate our ordinary understanding of morality. ${ }^{3}$ In her moral reasoning, the common agent, even without any philosophical background, 'stands as good a chance of hitting the mark as a philosopher can ever expect; indeed is almost more sure in this than even the latter' (IV:404.23-25). Kant's practical philosophy rests on the assumption that the common agent is a fully functioning moral agent. The competence of the common agent even leads Kant to wonder whether or not practical philosophy is necessary at all (IV:404.28-30, V:36.7-8). ${ }^{4}$

In the preface to the Groundwork, Kant explains that his method will be to start with common cognition, determine and examine its principle, as well as the sources of this principle, and take the route 'back to common cognition, in which we find it used' (IV:392.21-2). ${ }^{5}$ The title of the first section of the Groundwork announces a transition from our common moral rational cognition to philosophical cognition. ${ }^{6}$ The supposedly common notion of the unconditional value of the good will, as well as the verdicts of common rational capacities regarding exemplary cases, discussed in this first section, serve as a starting point for Kant's enquiry (see also XX:340.26-341.6).

Kant begins the Groundwork's first section with his famous claim that it is not even possible to think of something to be unconditionally good except a good will. ${ }^{7}$ If not every single agent, then at least 'common reason' is in 
'agreement' (IV:394.32-6) with Kant's take on the unconditional goodness of the good will, Kant believes. Kant does not take his assumption about moral goodness to be a philosophical invention, but an explication of what the common agent is already committed to in her reasoning about morality: Moral commands are unconditionally valid. The moral law has a firm grip on the agent, and the agent is aware of this. For common agents practical cognition 'comes together with unconditional bindingness', or with the consciousness of absolute authority (see VI:181.33-4, VI:481.31-6). ${ }^{8}$

Not only does the common agent understand that morality comes with a special normative force that is not based on anything contingent. She is, according to Kant, also able to employ universality, a rational criterion, in her ordinary reasoning about what ought to be done in a concrete situation (IV:402.7-13). Kant presents the universalisation test, which is given an abstract and universal formula by the Universal Law Formulation of the Categorical Imperative, as what common agents 'always actually have before their eyes and use as the standard of judging' (IV:403.36-7). In morally relevant situations the common agent can apply her insight into the significance of universality by asking herself 'would I actually be content that my maxim [...] should hold as a universal law' (IV:403.5-8)??

Common rational capacities function as a pre-philosophical 'standard' (IV:403.37, see also V:155.13-9). They reliably guide reasoning about morally relevant cases. The common agent, however, lacks 'insight (IV:403.27) into the underlying structure of her judgements and reasoning. The insights afforded by common rational capacities are unreflective (VII:58.18-30), 'obscure' (IV:450.37-451.1, $\mathrm{V}: 228.18-20,238.6-11, \mathrm{VI}: 216.32-3,376.25-6, \mathrm{XX} 226.16-31)$, or appear as a mere feeling, not as a rational and necessary cognition to her (IV:451.1), and manifest themselves only in reasoning about concrete cases. ${ }^{10}$ Common agents lack an explanation for $w$ by their judgements about concrete cases are correct, and they lack a reflected defence of their way of reasoning. It is the philosopher's task to 'bring to light' (IV:397.3) or 'develop' (ibid. 6) what is already present in the common use of reason, and make the common agent aware of or attentive to her own principle (see also VI:183.20).

The common agent's rational and moral abilities and insights raise the question as to why a philosophical systematization and vindication of the common way of reasoning is useful at all. This question is answered in the penultimate paragraph of Groundwork I (IV:404.1-405.19). The common agent is caught in a 'natural dialectic' (IV:405.13). The dialectic is not something accidental, but due to the double nature of finite rational agents, i.e., due to the tension between unrelenting moral commands rooted in finite agents' rational nature and their natural desire for happiness rooted in their sensuous nature. ${ }^{11}$ The common agent is in a state of 'fortunate simplicity' (IV:404.34), since she has a conception of goodness that is not skewed by 'alien and irrelevant considerations' that confuse 


\section{Martin Sticker}

and deflect the evaluations of the philosopher (IV:404.25-28). However, without a justification that enables to defend her practical cognitions, an agent is 'easily seduced' (IV:405.1). Seduction is a temptation with a cognitive component, namely with a story of why it would be permissible in a certain situation to give in to sensuous incentives.

When an agent gives in to temptations she begins to 'rationalize' [vernünfteln] (IV:405.14): to cast doubt on some features that are, according to Kant, essential for a correct conception of the morally good, namely 'strictness' and 'purity' of the moral law, and maybe even on its 'validity' (IV:405.14-5). Rationalizing means inventing seemingly compelling but normatively ungrounded stories, supposed to justify exceptions to the moral law, and to 'transform' (IV:424.31) one's awareness of what ought to be done into a conception that is more lenient and allows more room for our 'dear self' (IV:407.25-6). Rationalizing is a process that unfolds within common reason itself. An agent adapts her conception of morality to her desires, and this 'corrupts' (IV:405.17) a common agent's conception of the good, and ultimately her character, since an agent who is caught in the web of her rationalizations does not put duty first. On the contrary, she has conditioned obedience to the moral law on exceptions and qualifications.

The danger of corruption impels the common agent 'to seek help in philosophy' (IV:405.32-3). Practical Philosophy can make agents attentive to their own principle (see IV:404.5) by identifying the principle that underlies the moral appraisals of the common agent, and by giving it an abstract, and universal formulation. This happens in Groundwork II. From practical philosophy the common agent can also receive 'intelligence and distinct instruction regarding the source of this principle' (IV:405.23-27, my emph.). This is the task of Groundwork III. Practical philosophy as Kant advocates it proceeds in three steps: It identifies what the common agent is committed to when she reasons about concrete cases; it systematizes the concepts and principles identified in this reasoning, and spells out their implications and relations to each other in the form of a theory; it vindicates this theory by showing that the theory has a rational source. ${ }^{12}$ Kant hopes that uncovering the source of morality and showing that rational agents in their ordinary reasoning are already committed to the proposed grounding of morality, can serve as a protection and 'antidote' (Wood 2002: 28) against the corrupting influence of rationalizing. ${ }^{13}$

A pure practical philosophy, which can provide this protection and antidote, is 'a desideratum of the highest importance' (IV:410.24). To establish such a practical philosophy, Kant in Groundwork II first surveys and criticises popular philosophical approaches to moral goodness as inadequate responses to the natural dialectic. He shows that the common agent's moral evaluations are not arbitrary, but guided by a rational principle that finds its philosophical formulation in the various Categorical Imperative formulae. Whilst the first two 
Groundwork sections presuppose the correctness of the common way of reasoning (Groundwork I), or the validity of the underlying abstract and universal principle (Groundwork II), and aim to 'identify' the supreme principle of morality, Groundwork IIII aims to 'corroborate' or vindicate this principle (IV:392.4), or to show that it is unconditionally binding for creatures like us (see IV:440.20-32, 447.8-14).

Common rational capacities are important for the Groundwork on the level of assessment of single cases, formulation of moral principles that underlie this assessment, and justification of these principles. They are most important on the first of these levels, since there they generate or deliver material for philosophical systematization. On the second level they merely 'agree' that there must be a formal law as a principle for the will, 'if duty is not to be as such an empty delusion and chimerical concept' (IV:402.12-3), and Kant's entire conception a mere 'phantasm' (IV:445.9). On the third level they confirm the metaphysical case Kant makes for his conception. Kant wants to emphasize that even in his most abstract conceptions and operations, which can only be the result of philosophical reflection, he does not leave behind what common agents are already committed to insofar as they reason about certain moral subject-matters in an ordinary way. ${ }^{14}$

Confirming the correctness of a complex philosophical operation cannot mean that the common agent on her own can perform the deduction, or that the deduction will be easy for her to understand. After all, controversies in the Kant literature concerning many aspects of the deduction show that the deduction is, if at all, not easy to grasp even for philosophically trained readers. It is the 'correctness' (IV:454.21) of the deduction that is confirmed, not the entire operation. Confirming the correctness, presumably, means that the result or conclusion of the philosophical operation is not alien to a common agent. The deduction spells out and at the same time grounds important elements of the self-understanding of the common agent and it does it in such a way that the common agent can still recognize these elements in the philosophical argument.

\section{Common Rational Capacities and the Deduction}

The aim of Kant's deduction is controversial; it is not entirely clear whom Kant wishes to address, or convince, and what Kant takes to be the burden of proof on him when engaging his intended audience. Kant explicitly says that the aim of the deduction is to show 'whence the moral law is binding' (IV:450.16), i.e., where the special status of morality comes from, or what its source is: Prudence, divine command, reason, etc.? Already in Groundwork II when discussing the differences between hypothetical and categorical imperatives, Kant foreshadows that the aim 


\section{Martin Sticker}

of the deduction cannot be to discuss whether the Categorical Imperative is binding. The 'only' question that stands in need of a solution is 'bow the imperative of morality is possible' (IV:419.12-3, my emph., see also IV:420.21). The explanation of how Categorical Imperatives are possible is supposed to make clear that it is not the case that Categorical Imperatives are hypothetical (IV:419.15-9), as someone who buys into a mistaken conception of the source of morality might suspect. ${ }^{15}$ If Kant wishes to address a sceptic in Groundwork III, it is a sceptic of a particular kind, namely one who accepts moral commands, but believes that they have to be obeyed for reasons of prudence or self-interest. It seems questionable whether we would call this person a 'sceptic', since she agrees with the Kantian philosopher concerning the question as to which actions ought to be performed or omitted. At most she is a sceptic concerning the source of morality. ${ }^{16}$

The task of the deduction is of an explanatory nature: The common agent already recognises the moral law as authoritative (see section I), but she might wonder what the foundation of the special status of the moral law is, and how it is possible that she, as a creature who vividly experiences the force of sensuous needs and inclinations, is under moral obligations. This task requires an inquiry into the source and metaphysical background of our ordinary understanding of morality, or into what we are committed to insofar as we pre-theoretically reason about morality. It is important to note that one can have a commitment without being aware of this. When I believe 'A implies B' and 'A', I am committed to 'B', though as a matter of fact I might not believe ' $\mathrm{B}$ ' (not even implicitly). In fact, I might even believe 'not-B'. Once my beliefs in 'A' and 'A implies B' are clearly presented to me, I will see that ' $\mathrm{B}$ ' is a coherent, and even necessary part of my system of beliefs and assent to 'B' (or alternatively revise my belief in 'A implies B', 'A', or, most drastically, in the validity of modus ponens).

The deduction can be understood as spelling out the ultimate commitment of what the common agent is doing, when she engages in rational ${ }^{17}$ deliberation: reasoning from a rational or intelligible point of view. In what follows, I will show that the common agent can be content with the result of the complicated philosophical deduction, since the deduction draws on the notion of a special, intelligible standpoint that the common agent is disposed to accept, since the possibility, actuality, and supreme value of this special standpoint can be traced back to the way she reasons about the world, herself and morality.

In the first sub-section of Groundwork. III, Kant starts his argument with the notion of freedom as the 'key to the explanation of autonomy' (IV:446.6). He introduces what is sometimes called the 'Reciprocity Thesis': the claim that freedom and the moral law are reciprocal concepts. ${ }^{18}$ In the second sub-section, he argues that freedom needs to be presupposed as a property of the will of all rational beings, and that morality 'must be derived solely from the property of freedom' (IV:447.32-3). 
These two sub-sections have already on their own ignited much debate in the literature. ${ }^{19}$ I cannot say more about them here, and will begin my discussion with Kant's worry that his argument from freedom to morality might be circular. We 'take ourselves as free in the order of efficient causes in order to think ourselves under moral laws in the order of ends' and 'afterwards think ourselves as subject to these laws, because we have already ascribed to ourselves freedom of the will' (IV:450.19-23). We can phrase this circle as follows: Why do we consider ourselves free? Because we think of ourselves as subject to moral laws. Why do we think we are subject to moral laws? Because we attribute to ourselves a free will. ${ }^{20}$

According to Sussman (2008: sec.1-3), Kant does not worry about a possible logical blunder in his argument, but rather that his argument in the first two sub-sections might only show that morality can motivate free agents, but not that its normative force always trumps inclinations. Something other than a logical fallacy might be the issue in the first sub-sections, and hence what is to be expected is not so much a simple disambiguation of terms, which would resolve a circle, but something that furthers Kant's argument in a different way. We will come back to this idea when discussing the scoundrel below.

Kant declares that the suspicion of circularity is 'removed' (IV:453.3) by the notion of two different 'standpoints' (IV:452.25-6) that an agent can take up. She can consider herself from an empirical standpoint as a member of the sensuous world, in which she is subject to laws of nature. She can also consider herself from an intelligible standpoint as a member of the world of understanding, in which she is subject to laws of reason (IV:452.26-30). ${ }^{21}$ Transferring oneself in thought into the world of understanding helps to become aware that one is an autonomous agent. Insofar as we conceive of ourselves as obligated by moral commands we think of ourselves as part of both, the sensuous and the world of understanding (IV:453.3-15).

It seems that the discussion that leads to the alleged circle, instead of being Kant's main argument that still stands in need of some terminological disambiguation, is rather supposed to merely set the stage for Kant's introduction of the different standpoints. As a result of the introduction of the two standpoints, Kant takes himself to have established that finite agents acknowledge that they are under moral obligation, and he takes himself to have provided a rationale or source for this, namely, our membership in the two worlds, and particularly in the world of understanding. Providing this rationale or explaining where our obligation comes from is the aim of the deduction. By understanding that she is a member of both worlds, an agent understands that there is a law different from the laws of the sensuous world. This, however, only gives us the moral law, the law of this other world, not the Categorical Imperative, which is the moral law plus unconditional authority. Kant needs to establish that the 


\section{Martin Sticker}

law of this other world ought to govern the actions of finite rational agents unconditionally.

Kant assumes that the world of understanding contains 'the ground of the world of senses, and hence also its laws' (IV:453.32). ${ }^{22}$ The, at best, 'sketchy' (Timmermann 2007: 140) argument that Kant gives for the priority of the intelligible is, in short, that the world of understanding can necessitate agents, whereas the sensuous world cannot. The laws of the world of understanding are represented by the agent as unconditionally necessary and demand strict and exceptionless obedience, whereas the laws of the sensuous world are cognized without normative authority. ${ }^{23}$ There would be no reason not to break laws of nature, if we could break them, whereas a violation of the Categorical Imperative is followed by feelings of guilt, remorse, pangs of conscience, etc., because agents commonly think of moral laws as something normative that cannot be transgressed merely because one has an inclination to do something that can only be done by transgressing these laws. If agents could break laws of their sensuous nature, they would not experience a similar pressure to excuse or seemingly justify their doing. ${ }^{24}$ Kant later provides a related argument, when he calls an agent's rational self her 'proper' self (IV:457.34, 458.2, 461.4), indicating that there are certain ontological reasons, or perhaps reasons based on a certain kind of authenticity, to follow intelligible laws. ${ }^{25}$

Considering oneself from an intelligible standpoint is of pivotal importance in explaining how the moral law obligates an agent. The contribution of common rational capacities to the deduction is to show that the intelligible standpoint is not simply the standpoint of the philosopher, but rather a standpoint available to every rational agent, and that the common agent accords a higher status or value to the world of understanding. Kant provides three considerations intended to show he is drawing on commitments of common agents. The first draws on theoretical insights of the common agent (1), the second and third refer to the practical (2) and moral (3) understanding of the common agent. ${ }^{26}$

(1): In a digression, Kant claims that even 'the commonest understanding' (IV:450.36-7), without 'subtle thinking' (IV:450.35-6) is aware through 'an obscure distinction of the power of judgement, which it calls feeling' (IV:450.37$451.1)^{27}$ that we, as finite human beings, can only cognize appearances, never things as they are in themselves (IV:451.1-8). As a result we assume behind the appearances something that is not appearance, namely things in themselves or a world of understanding (IV:451.8-24). That an agent can have no experience of the world of understanding holds even for the intelligible part of that agent herself (IV:451.31, B:157-9). The agent is, however, aware that part of herself belongs to the world of understanding (IV:452.23-30).

Kant stresses that the inferences drawn from the obscure insights into the possibility of a world beyond experience are 'presumably also to be found in the commonest understanding' (IV:452.1-2). Common understanding, however, 
'spoils' (IV:452.4) its insights by treating the world of understanding as if it were simply another, albeit epistemically removed, sensuous world. According to the common agent, the reason why there are entities that are 'completely unknown' (A/B:42/59, see also A/B:494/522-3), is that these entities cannot be experienced for contingent reasons (they might be too far away, too small, etc.) (IV:452.4-6).

Kant here attributes insights to common rational capacities that, according to some interpreters, amount to 'an argument for transcendental idealism from the material available to ordinary reason' (Tenenbaum 2012: 582). Not only is a common agent aware of the limitation of her finite capacities to cognize the world, she also has some grasp of the implications of these limitations: She understands that it is possible that there are things or a 'world' of things that she cannot cognize. The common agent, however, lacks a firm grasp of how fundamentally different this 'world' is, and does not understand that finite agents, in principle, cannot cognize the world of understanding.

There are many thorny issues pertaining to Kant's distinction between the sensuous and the intelligible. The most prominent of these is the question as to whether this distinction is one between different worlds, or between different aspects of the same world. ${ }^{28}$ Kant points out that the distinction he makes in Groundwork III is 'rough' [roh] (IV:451.18), and later adds the caveat that the distinction serves practical purposes only (IV:457.4-459.31). In Groundwork 450-2, Kant does not intend to elaborate on his conception of transcendental idealism. His aim is to describe how the common agent tries to make sense of her insight that her rational or cognitive capacities are finite, or that her experiences have limits. ${ }^{29}$ The common agent is aware that the sensuous world cannot be all there is, and that there has to be a world removed from the causal order of experience. Viewing the world and oneself from the perspective of such a noncausal world means taking up the intelligible standpoint. ${ }^{30}$

(2): Kant's considerations in (1) only show that the common agent can envisage the possibility of another than the empirical standpoint. Kant also thinks that the intelligible standpoint is, at least implicitly, often frequented by common agents.

Kant believes that 'all human beings think of themselves as having a will that is free' (IV:455.11), and that this presupposition is necessary for every rational being. ${ }^{31}$ Having to act under the idea of freedom is equivalent to freedom 'in a practical respect' (IV:448.6). Kant maintains throughout his critical writings that common agents do not understand the foundation of freedom, or how freedom is possible (IV:456.8-9, 458.36-459.31), and that from a theoretical perspective we cannot be certain that we are free, and that the foundation of freedom is 'inscrutable' [unerforschlich] (VI:138.19), and 'not given to us for cognition' (VI:138.20). Nonetheless, the conviction that we are free will never be 


\section{Martin Sticker}

'wrested' (V:134.2) from 'even the most common human being' (V:134.1-2). Kant even attributes to a newborn child 'an obscure idea $[\ldots]$ of freedom' (VII:269fn.).

There is much debate about how to understand Kant's 'bald assertion' (Allison 2012: 113) that we necessarily have to act under the idea of freedom, and that this is more than a heuristic fiction or an illusion of freedom. Kant is trying to articulate the insight that, no matter what the natural sciences discover and teach about the world, rational agents necessarily have the impression that they are not (always) compelled by their desires, but can reflect about desires, and rationally deliberate about their options. ${ }^{32}$

Agents, insofar as they act, i.e., do something as the result of rational deliberation, are committed to the notion that they are free, or they have to assume this, and they can, upon reflection, become aware of their freedom. Jeanine Grenberg (2009: 341; 2013: ch.5) argues that 'freedom' in Groundwork III should be understood not in a morally qualified sense, but as 'negative freedom' with a 'slight movement beyond negative freedom' (Grenberg 2009: 349). What Grenberg has in mind is the everyday experience of acting without coercion and bringing about consequences in the external world that we can recognize as the consequences of our doing, and that make us aware of our freedom (ibid. 340-1). ${ }^{33}$ Such a deflationary account of freedom as (mainly) negative makes plausible Kant's claim that agents who deliberate about their actions are committed to being free and can become aware of their freedom. After all, deliberating only has a point when we assume that we are in principle able to bring about consequences as a result of our decisions. Kant's claim that we must necessarily act under the idea of freedom is certainly more contentious if we assume a morally loaded conception of freedom. ${ }^{34}$

Awareness of their freedom transfers agents into the rational order of things; an order they, as a result of understanding of the limitations of their cognitive capacities, deem to be possible. Through their awareness of freedom, common agents understand that different laws apply to them insofar as they transcend the causal order of things. The deduction, in so far as it draws on the special point of view of free agents, appears to these agents as a natural extension of this standpoint. The intelligible standpoint is the standpoint that common agents take to be their standpoint insofar as they are aware that they are free (IV:455.1-4). Without an agent's capacity to become aware of her freedom, the deduction would be utterly unconvincing for this agent, since the deduction would seem to her like a manoeuvre drawing on the commitments of a metaphysically different kind of being.

(3): After his deduction ${ }^{35}$, Kant provides his most explicit illustration of how 'the practical use of common human reason' (IV:454.20) confirms the correctness of the deduction. Even the 'most hardened scoundrel' (IV:454.21), an agent in the 
grip of inclinations but nonetheless rational, is, according to Kant, still able to recognise 'examples of probity of purpose, of steadfastness in following good maxims, of compassion and of general benevolence' (IV:454.23-25), and to acknowledge the 'repute' (IV:455.6) of the moral law, i.e., that the moral law imposes obligations on him.

The examples of moral conduct necessitate the scoundrel to 'transfer himself in thought in an order of things quite different' (IV:454.31-2): the world of understanding. As a member of the world of understanding the scoundrel is aware of his ability to be guided by a law of reason, which 'by his own admission' (IV:455.5-6) constitutes the law of his will. The sensuous scoundrel might rebel against the commands of morality, the rational scoundrel, by contrast, experiences morality as his 'own necessary willing' (IV:455.7). The scoundrel, when presented with examples of outstanding moral conduct, wishes that he might be 'disposed' (IV:454.27) like the person in the examples. Kant's idea is that a rational agent can be brought to acknowledge the authority of the intelligible standpoint via examples of conduct that demonstrate that creatures like the agent, and indeed he himself, are able to deliberate and to act from the rational standpoint.

Even commentators who are generally sympathetic to Kant, such as Henry Allison, charge the scoundrel case with psychological implausibility. Kant assumes that upon encountering examples of morally good conduct, the idea of freedom 'without his choosing necessitates' (IV:455.3-4) the scoundrel to view himself as part of the world of understanding, and that it is not possible for the scoundrel to simply 'scuff off the manifestation of goodness' (Allison 2011: 342). One important factor that bears on the plausibility of the scoundrel case is what it means for the scoundrel to be 'otherwise in the habit of using reason' (IV:454.22). It certainly means that the scoundrel is endowed with instrumental rationality. The scoundrel is also, at least potentially, still capable of moral deliberation. After all, 'scoundrel' is an evaluative term that shows that Kant thinks the scoundrel can be subject to moral criticism. ${ }^{36}$

The scoundrel is an agent who fails to do what he is, in some sense, aware of as obligatory, and who feels justified in doing so, because his insight into what ought to be done has lost clarity and salience. The scoundrel, admittedly, cannot be entirely corrupted. He might not be able to give the right answers to morally relevant questions right away, but he at least has the ability to recognize morally worthy conduct when it is pointed out to him. The insights of his common rational capacities are not entirely lost, but clouded, or eclipsed by rationalizing (see section I). The scoundrel is confused about morality, in the sense that he does not think thoroughly enough about morally relevant subject-matters to fully appreciate the majesty of the moral law. He has a story that he tells himself to justify his conduct to himself. 


\section{Martin Sticker}

The scoundrel's change of attitude becomes more psychologically plausible when we take Kant's claim that we have to present 'examples' (plural!) (IV:454.23) seriously. Kant does not believe that presenting a single case of morally good conduct is sufficient. Dealing with the scoundrel might be pulling teeth. We have to present numerous and various examples, engage the scoundrel in dialogue, explain certain background assumptions, etc. Kant appeals to Socrates (IV:404.4) as a methodological paradigm of philosophy and moral education, because Kant is aware that sometimes a dialogue or critical exchange, and even showing that certain convictions are unfounded and lead into an aporia, are required to set corrupted agents right.

Kant does not assume that the scoundrel can change his disposition 'easily' $(\mathrm{IV}: 454.28)^{37}$, but only that, after hard work, the scoundrel can be brought to acknowledge that he is subject to the laws of the rational order of things. In addition, Kant stresses that the scoundrel's acknowledgement of the repute of the moral law occurs as the scoundrel 'transgresses' (IV:455.6-7) this law. The scoundrel does not change his behaviour, but only becomes aware that he does not live up to the standards of his rational self, and that the perspective he takes up when he makes use of his rational capacities enjoys normative priority over his sensuous self.

Kant's assumption is that an agent endowed with common rational capacities always has, at least with the help of a philosopher or educator, enough rationality left to take up the rational point of view, and to acknowledge that this standpoint is normative and higher than the sensuous standpoint and the needs and inclinations that come with it. The worry with this assumption is, I think, not so much its psychological plausibility but rather the question as to whether this is sufficient to establish what Kant wishes to show, namely that the law of reason is not merely normative, or of greater importance than inclination, but that it is unconditionally binding, and can never be outweighed or overwritten by inclinations or the enticing appeal of happiness. This is a version of the worry that Sussman sees at the bottom of what Kant thinks is the circularity problem: Morality might be normative, but its normative force might fail to always trump inclinations. As I see it, nothing in the scoundrel case shows that the scoundrel acknowledges more than the 'greater inner worth' (IV:454.37) of his rational self. This is, however, very different from the unconditional worth of morality. The scoundrel case is only a partial confirmation of Kant's deduction. ${ }^{38}$

Kant's discussion of rationalizing at the end of Groundwork I as something that hinders or perverts moral cognition suggests that Kant's goal is to help common agents gain a better understanding of the source of morality. This is certainly the case, but the scoundrel case also shows that Kant does not detach questions of motivation from this better understanding. The scoundrel does not merely understand that his behavior was and is wrong, but also wishes that he could act differently (though this wish might still be too weak a motive to actually 
How can Common Rational Capacities Confirm the Correctness of the Deduction in Groundwork III-and Why does it Matter?

move him to moral actions). ${ }^{39}$ Kant believes that the membership in a world of understanding, which philosophy can make an agent aware of, affects the agent's motivation and can be a tool for moral improvement.

\section{Conclusion}

On the one hand, common agents can gain something from the deduction, namely, an understanding of the source of morality that helps to block the natural dialectic, and on the other hand, they have a contribution to make to the deduction. They perform two functions for the deduction which can be understood as a confirmation. Firstly, due to insight into the limitation of their cognition of the world, common agents deem the metaphysical background of the deduction (the world of understanding) at least possible, and when they are explicitly made aware of their membership in the world of understanding, they, and even the worst of them, express a changed attitude towards morality (though not necessarily a changed disposition, since scoundrels only wish they were disposed in a more moral way). This contribution corresponds to (1) and (3), and it does not affect Kant's philosophical argument. It shows, however, that the deduction as a philosophical operation can assist not only the philosopher, but even common agents, since common agents can recognize the philosophical operation as explicating their fundamental metaphysical and moral commitments. This confirms the practical relevance of the deduction.

Secondly, one of the central premises of the deduction is that agents necessarily have to think of themselves as free from a practical perspective. Kant draws on the practical self-understanding of an agent endowed with practical reason. A common agent's experience of changing the world as a result of deliberation and as not being irresistibly compelled by her most immediate impulses confirms that Kant's premise captures agency as it appears to the agent herself. This contribution corresponds to (2), and, as I understand it, affects the viability of the deduction itself, since if Kant's claims about our freedom would find no confirmation by ordinary people, we would have to assume that Kant in Groundwork III deduces for other creatures than finite rational human beings (maybe for Kantian philosophers only). This would make it doubtful that the deduction, and Kant's entire conception that is to be vindicated by the deduction, can claim universality, in the sense that it applies to all finite rational beings.

\section{The point of having the Common Agent on one's side}

The confirmation of the deduction by common rational capacities shows that Kant, in the Groundwork, does make his way from judgements of common agents 


\section{Martin Sticker}

about concrete cases of moral relevance back to the commitments of common agents. He begins with common propositions about morality, and the way in which common agents reason about morally relevant cases, and he concludes his argument with the scoundrel, an agent who confirms one of the central elements of his deduction, because he has enough reason left to acknowledge the repute of morality. ${ }^{40}$ The confirmation of the deduction by common rational capacities shows that Kant's complex philosophical operation can become popular. It is, in principle, accessible to the common agent, or can be communicated to this agent in a way that she can understand, because the deduction spells out some of her fundamental commitments regarding the limits of her cognitive abilities, and her awareness of freedom and morality.

The structure and aim of the Groundwork suggest that the confirmation of the common agent is not a manoeuvre to gain additional philosophical credibility in debates with academic colleagues. Kant must have been aware that it would be anything but easy to convince his colleagues that the common agent, or what he takes to be the common agent, is more trustworthy and delivers better material and confirmation for moral philosophy than the views of professional ethicists. The deduction is supposed to address the worry raised at the end of Groundwork I: The common agent stands in need of a clarification, systematization, and vindication of her judgements, and their underlying assumptions, in particular in need of a better understanding of the source of morality, since everything else hinges on this source. An agent who wants or needs more than an abstract principle and a systematization of concepts, because she is seriously confused about the morally good, or simply persistent in her critical questions, can only be helped by the content of Groundwork. III.

The deduction serves a practical purpose. It is supposed to uncover means to address forms of corruption that can arise as a result of rationalizing, namely attempts to conceive of the moral law as admitting of (occasional) exceptions, or that moral commands might not be unconditionally binding, but can be outweighed by expected consequences of actions, or by the impact an action would have on an agent's life and happiness. ${ }^{41}$ Kant thinks that these challenges can be addressed by showing that our ordinary notion of obligation is founded on reason or on membership in a world of understanding (and hence is universal in scope, does not admit of exceptions and cannot be rationally outweighed), and he thinks that this response has to be given in such a way that not only people with a background in philosophy can benefit from it.

Kant is fully aware that it is unrealistic to assume that many common agents will work through Groundwork III. Practical philosophy is, according to Kant, not supposed to be immediately action guiding. Instead, philosophy is supposed to establish a 'doctrine of wisdom' (V:163.28), and this doctrine can 'serve teachers as a guideline to prepare well and clearly the path to wisdom which everyone should 
travel, and to secure others against taking the wrong way' (V:163.29-31). The function of practical philosophy in the Groundwork and the Second Critique is to inform popular philosophers and educators, and thereby to indirectly influence the moral education of people who lack a philosophical background. Only philosophy in whose 'subtle investigations' the public has to take no interest, can present a doctrine of wisdom with sufficient clarity regarding the formulation, source, and bindingness of a supreme principle of morality to facilitate a moral education that is sufficiently clear, rigorous and theoretically grounded (V:163.33-35). Practical philosophy has to determine the guidelines of moral education by uncovering our common conception of morality, and by showing how this conception can be grounded and defended. ${ }^{42}$

The confirmation of common rational capacities does not establish that there cannot be a more sophisticated, or better founded account of the supreme principle of morality or of its source. It is supposed to show that even the most abstract part of the Groundwork still can serve Kant's overall project to vindicate the common perspective in a way that can be of practical use or that can be relevant for everyone. The confirmation of the deduction can be understood as Kant's response to what Nietzsche calls 'Kant's Joke':

'Kant wanted to prove, in a way that would dumbfound 'the whole world', that 'the whole world' was right: that was the secret joke of this soul. He wrote against the scholars for the sake of the people's prejudice [Volks-Vorurteil], but for scholars and not for the people.' (Fröbliche Wissenschaft sec.193, my trans.).

It is true that Kant wrote for scholars, but he was convinced that scholars could translate his defence of the common agent into a language that would not dumbfound, but protect and better the people.

This optimism is a second sense in which Kant makes his way from the common cognition of duty back to the common cognition. His philosophical investigation and vindication of the common cognition has the potential to positively affect the common cognition of duty. Appeal to common rational capacities is part of a 'pedagogical strategy' (Schönecker 2009: 110). Philosophy can improve the way agents conduct their moral business, since it does not start as, and never becomes something that is alien to our ordinary practices. It is hence always possible to link the results of practical philosophy back to our practices and to modify our practices in light of the principles that we commit ourselves to when engaging in these practices. Ordinary agents and philosophers do not speak two radically different languages, and hence the philosopher, if she has something to say to the common agent can make herself understood, or the educator can at least translate between philosophy and ordinary agents. 


\section{Martin Sticker}

Kant believes that his philosophy is different from theoretically sophisticated, 'alien and irrelevant considerations' (IV:404.27-8), and 'perplexing speculations of the schools' (V:35.16-18), which can deflect ordinary judgements from the straight course. Unlike these purely theoretical approaches to morality, Kant never loses sight of what he takes to be the point of practical philosophy: strengthening an agent's 'receptivity to a pure moral interest' (V:152.33-35, see also A/B:829-30/857-8) with the goal of 'cultivating and founding genuine moral dispositions' (V:153.11). ${ }^{43}$ Kant believes that, if correctly communicated, making common agents aware of what they assume in their ordinary reasoning will secure their understanding against rationalizing, and the misleading philosophy rationalizing produces, as well as make them wish that they could be exemplary moral agents and, perhaps, even motivate them to strive towards this goal. ${ }^{44}$

\section{Martin Sticker \\ University of St Andrews, University of Stirling, ms752@st-andrews.ac.uk}

\section{Notes}

1 See Engstrom (1997), Ameriks (2000; 2006), Guyer (2003), Uleman (2010: 80-107), Sticker (2011; 2015: sec.1). Most recently Grenberg (2013) has published a book-length treatment of the role of ordinary moral experience for Kant's ethics. Of those who emphasize the role of our ordinary understanding of morality Grenberg (2009; 2013) deals most extensively with the deduction. I cannot critically assess Grenberg's innovative conception of Kant's alleged phenomenological method of ethics here. See my review (Sticker, 2014) for indication of differences between Gremberg's and my approach to common rational capacities.

2 See IV:403.18-22, V:27.21-2, 36.28-35, VI:48.17-33, 181.28-24, 481.22-482.4.

3 This becomes particularly apparent in V:8fn., and VI:216.28-34.

4 That Kant indeed thinks that common rational capacities are more reliable than the more reflective judgements of the theoretician is confirmed in A/B:831/859, V:35.16-18, 155.12-18, IX:78.32-79.19, XX:300.37-301.12.

5 Bittner (1989: 29), and Schönecker, Wood (2007: 17-8fn.13) express doubts regarding Kant's announcement that he will make his way back to the use of the supreme moral principle in common reasoning.

${ }^{6}$ Engstrom (1997: 16) believes that the common rational moral cognition referred to in the heading of Groundwork I is not what I call 'common rational capacities' but traditional (ancient) ethical philosophy. In contrast to Engstrom, I believe that the fact that Kant dismisses rival virtue ethical candidates at the beginning of Groundwork I does not entail that Kant's own candidate for unconditional goodness is a virtue ethical remnant. The opposite is the case: 


\section{How can Common Rational Capacities Confirm the Correctness of the Deduction in Groundwork III-and Why does it Matter?}

Kant discovered something completely un-virtue ethical in our ordinary moral reasoning: a necessitation that does not depend on our desires or on prospect of happiness.

7 See Ameriks (2003: ch.7) for a discussion of the three main interpretations of the good will: the good will as a particular intention, as a general capacity, and as the whole character.

${ }^{8}$ See also IV:424.34, V:31.27-33, 35.14-5, 44.19-22, 80.2, 91.22-3, 151.13-152.18, 435.18-9, VI:36.1-7, VIII:286.13-37, 402.21. According to Baxley (2010: 2), Kant's claim about the sole unconditional goodness of the good will has 'struck many readers as counterintuitive', since it ignores the importance and value of 'morally favorable emotions and inclinations'. Baxley dedicates her book to showing that particularly Kant's late conception can accommodate emotions and inclinations to a sufficient extent.

9 See also IV:421.24-423.35, V:27.22, 36.4-6, 44.2-3, 69.22-24.

10 See IV:403.25-33, V:155.12-18, VII:139.18-26, IX:17.17-26, 19.9-16, 27.3-12.

11 See IV:415.28-33, 418.1-4, VI:45fn., VIII:278.15-21. Schönecker (1997: 324-6) in particular emphasizes that the natural dialectic is rooted in the 'double nature' of human agents.

12 These three steps roughly coincide with the three parts of the Groundwork. See also Deligiorgi (2012: 52) who argues with reference to V:9-10 that Kant proceeds from a delineation of pre-theoretical basic moral concepts, to an exposition of how these concepts fit together, and a final derivation or vindication.

13 Thorpe (2006) emphasizes the practical aim of the Groundwork. See Guyer (2003: 19-30) for more on the role of philosophy as a response to the natural dialectic. The significance of rationalizing for Kant is by no means limited to the Groundwork. Another passage that explicitly discusses rationalizing and its background is VI:377.13-378.31. Examples for rationalizing attacks on morality can be found throughout Kant's works. See for instance V:122.26-123.5, V:152.7-18, 156.7-21, 153.13-154.15-6, VI:38.1-33, 51.22-37, 168.8-170.11, VIII:379.32-35, IX:76.13-77.25, XXVII:359.8-28, 729.16-732.6. For more detailed discussions of rationalizing see Guyer (2000), Piper (2008), Schönecker (2009). For a discussion of rationalizing related to common rational capacities see Sticker (2012; 2015: sec.2.3). See Sticker, Van Ackeren (forthcoming, sec.3) for a discussion of rationalizing in the context of the debate about, alleged, excessive moral demands.

${ }^{14}$ In the Second Critique, Kant indicates a close relation between the Fact of Reason and common rational capacities. Kant claims that the fact of reason is 'undeniable. One only has to dissect the judgement, which humans make about the regularity of their actions' (V:32.2-3). The claim that pure practical reason can be practical on its own has to be established from the 'most common practical use of reason' (V:91.20). Since the Fact of Reason and its relation to common rational capacities is at least as intricate as the function of common rational capacities for the deduction, I defer detailed discussion to a different paper. Important recent literature for the relation between the fact and the ordinary moral perspective is Timmermann (2010), Schönecker (2013), Grenberg (2013).

15 In addition to controversies about the aim of the deduction, it is also controversial what the exact object of the deduction is: the categorical imperative (Paton 1946: 242, Schönecker 1999, Stankovic 2013), necessitation of the will (McCarthy 1982: 179), the moral law, consciousness 


\section{Martin Sticker}

of freedom, and the form of imperatives (all three Henrich 1998), freedom (Voeller 2001), the good will (Ludwig 2008). My reconstruction of the Groundwork argument so far suggests that the deduction's object is to reveal the source of morality as well as to show that rational agents already implicitly accept this source. This, I take it, is equivalent to proving the necessitating force of the will, morality, or the Categorical Imperative, since establishing the source of morality provides a rationale for the common agents' conviction that morality demands unconditional obedience.

16 See Timmermann's (2007: 120-52, esp.129-30) commentary for a full reconstruction of the deduction that assumes that the deduction is not concerned with refuting a full-blown sceptic, but as aiming to provide a metaphysical explanation of a principle that an agent already accepts. Philosophers who believe that Kant in Groundwork III wants to reply to a proper moral sceptic are Ameriks (2000: 75; 2003: 170), Guyer (2003), Kerstein (2002: 5), Allison (1998: 273). Philosophers who deny this are Hill (2012: 270-1), and Stern (2010: 463). The latter argues that Kant is addressing a sceptic who is committed to morality and still finds morality problematic or puzzling. This is certainly not a full-blown moral sceptic. Recently, Ameriks and Allison have changed their mind and acknolwedged that Kant does not intend to answer 'adamant' sceptics (Ameriks 2010: 46), but a 'curious and sympathetic meta-ethicist' (Allison 2011: 309). It should be kept in mind that even if Kant did not intend to engage with a sceptic in Groundwork III, his argument might be potent to address certain forms of scepticism. I am grateful to Jens Timmermann and Joe Saunders for many discussions about the aim of the deduction.

${ }^{17}$ For the question of whether the deduction is aimed at refuting a sceptic, it is crucial how to understand the notion of rationality here. If it is pure practical reason, then morality is already assumed, and the argument question begging if directed against a sceptic. If the deduction starts from the commitments of empirical practical reason only, it aims at a more ambitious argument from non-moral premises to morality. As I argued above, Kant is, if at all, only interested in refuting a very tame sceptic who already buys into morality.

18 See IV:446-7, V:29-30, as well as Allison (1990: 201-13; 1998; 2011: 273-300) for discussion and defence of the Reciprocity Thesis. Schönecker (1999: ch.3; 2006) refers to it as 'analyticity thesis'. ${ }^{19}$ Following IV:447.25 the first two sub-sections are often understood as a 'preparatory argument' (see for instance Allison 1990: 216-7). See Korsgaard (1996: 24-5) for a prominent attempt of a reconstruction of Kant's preparatory argument. See Tenenbaum (2012: sec.2) for recent criticism of Korsgaard based on her interpretation of what it means that we must act under the idea of freedom. Saunders (2014) defends the preparatory argument against some of the most important objections.

20 See McCarthy (1985), and Quarfood (2006) for a more detailed discussion of the circle in Groundwork. III. Schönecker (1999: 317-96) claims that there is no genuine circle in Groundwork. III, and Quarfood (2006: sec.1), and Allison (2011: 313-16) argue that there is a petitio principii rather than a circle. Quarfood (2006: sec.2) suggests that the circle does not represent a mistake that Kant thinks he himself might have committed, but that Kant tries to pre-empt a possible misreading of his argument by a Wolffian who cannot appeal to transcendental idealism for a grounding of morality. 


\section{How can Common Rational Capacities Confirm the Correctness of the Deduction in Groundwork III-and Why does it Matter?}

21 Allison (1990: 227-8) distinguishes between a world of understanding and an intelligible world and sees the failure of Groundwork III in Kant's inability to show how we can get from the one to the other. Since Allison (2011: 330fn.58) later distances himself from this charge, I will ignore this distinction.

22 The notion of an intelligible or 'archetypal world (V:43.27), the laws of which are obligations for finite agents, reappears in the Second Critique (see V:43.27-37). According to the Second Critique, however, the moral law, not awareness of freedom, 'transfers us, in idea' (V:43.30-1) into the world of understanding ( $\mathrm{V}: 43.30-37)$.

23 Note that I take Kant here to assume that common agents already accept moral commands as normative. Otherwise it is difficult to see what it could mean that the world of understanding contains the grounds of the sensuous world. My explanation of course presupposes that Kant's argument is not addressed at a full-blown moral sceptic.

24 The phenomenology of moral transgressions is described and elaborated on in later works of Kant. See V:87.11-88.15, VI:438.13-23.

${ }^{25}$ See Schönecker (2006: 137) for criticism of the 'higher ontic value' of an agent's proper self. See Sussman (2008: 63-5), Allison (2011: 335-337) for discussion.

${ }^{26}$ I follow a distinction from Grenberg (2013: 122-3). In her discussion of Groundwork III, Grenberg points out that not all practical insights are moral insights and would function as moral premises in an argument. Awareness of external or negative freedom is a practical matter that can function as a non-moral but practical (in the sense of non-theoretical) premise in an argument. Even a moral sceptic could accept certain propositions about freedom. In her earlier paper on the deduction, Grenberg (2009: 354fn.12) still seems to be unaware of this subtle distinction. There is substantial debate as to whether the deduction should be understood as an argument from non-moral premises, such as the Reciprocity Thesis, to moral conclusions (see Allison 1990: ch.12, 227-9; 2011: 326-330; Guyer 2007) or whether the starting point is an explicitly moral one (see Henrich 1998; Tenenbaum 2012). I will remain neutral regarding this question, since my paper only concerns the confirmation of the deduction, not the deduction itself. The third element of the confirmation, the scoundrel case, definitely does draw on moral insights.

${ }^{27}$ Kant here does not claim that common understanding is identical to, or concerned with a special kind of feeling. Common understanding is part of our common rational capacities, but it can, falsely, appear to a common agent, who lacks a clear insight into her rational endowments, as a feeling. In other words, common agents might think of some of their rational activities as a mere feeling, because they have never critically investigated their own understanding of metaphysical issues. An interpretation of the deduction based on the assumption that Kant here appeals to a special kind of first-personal, phenomenological feeling is advocated by Grenberg (2009: esp.339-40).

28 See Guyer (1987), Allison (2004), Chiba (2012) for critical discussion of Kant's transcendental idealism, as well as Allison (2011: 316-330) for extensive discussion of the Groundwork passage in question.

${ }^{29}$ Hence Allison's (2011: 324) worry that Kant's association of the two standpoints with the ordinary view leads 'to a complete distortion of the critical view' is unfounded. The Groundwork 


\section{Martin Sticker}

digression is concerned with the common agent's, not with Kant's own and more sophisticated, conception of transcendental idealism.

30 According to Timmermann (2007: 134), ' $[\mathrm{t}]$ he doctrine of the two standpoints reflects the way human beings intuitively conceive of themselves as agents'. Kant 'refers to the naïve belief in some hidden dimension that ground empirically observable things, and a human soul that does not belong to the material world' (ibid.).

31 See IV:448.9-11, 452.31-3. 456.1-3, 461.17-25, VI:35.9-17, VIII:13.6-14.20, XXIX:898.14-6.

32 See also Korsgaard (1996: 162): 'The point is not that you must believe that you are free, but that you must choose as if you were free. It is important to see that this is quite consistent with believing yourself to be fully determined'.

33 Grenberg (2009) sees the weakness of the deduction in Kant's inability to show how we can move from this awareness of freedom to an experience of moral obligation. In her reconstruction of the deduction she, however, ignores the scoundrel, even though in the scoundrel passage Kant comes closest to what the deduction lacks according to Grenberg: appeal to the experience of categorical necessity. Her criticism of the deduction thus seems forced.

34 Allison (2011: 226-30) emphasizes that establishing the common agent's membership in the world of understanding does not require moral insights.

35 The 'this' in 'the practical use of common human reason confirms the correctness of this deduction' (IV:454.20, my emph.) indicates that Kant refers back to a deduction he just completed.

36 This is even clearer for the German 'Bösewicht', which contains the morally loaded term 'evil'. In the Second Critique, Kant explicitly states that we can even hold 'born scoundrels [Bösewichter]' responsible for their actions. This is warranted, because a scoundrel's empirical character or his actions express his transcendental freedom or 'evil and unchangeable 778 principles freely adopted' (V:99.37-100.13).

37 Timmermann (2007: 153fn.51) argues convincingly that 'wohl' should be translated as 'easily' in this context.

38 Guyer (2009: sec.4), by contrast, worries that Kant establishes too much in his deduction, namely that the phenomenal agent is always determined by his proper, noumenal self, and that immoral actions become impossible. This problem is, according to Guyer, only solved in the Religion.

39 Kant's focus on motivation is already present in Groundwork II when he claims in a footnote that the practical use of his project of a pure practical philosophy, as opposed to popular philosophy, is vindicated by the 'most common observation', which reveals that 'when one represents an action of righteousness - as it was performed with a steadfast soul, without aiming at any advantage [...] it elevates the soul and stirs up the wish to be able to act like that too. Even children of intermediate age feel this impression, and one should never represent duties to them in any other way' (IV:411fn). That the scoundrel understands that morality is of higher value than objects of inclinations, but is still motivationally weak shows that Kant is aware that philosophical clarification does not automatically translate into a morally good 
disposition. See Sticker (2015: sec.2.) for discussion of the relation between philosophical clarification and motivation. For a recent treatment of the acquisition of a truly virtuous disposition, which requires controlling affects and desires, maintaining certain feelings and inclinations, and cultivating dispositions and attitudes, see Baxley (2010: ch.4). I am grateful to an anonymous referee for pressing me on the significance of motivation.

40 See Timmermann (2007: 134) who claims that from IV:450.35 onwards Kant 'begins to make good his promise to return to the view of common, pre-philosophical understanding'. ${ }^{41}$ It is important to note that these forms of corruption are not forms of moral scepticism, since rationalizing, the activity of modifying one's conception of morality to make oneself look more moral, presupposes that an agent buys into morality, and even is very concerned about her moral status. The rationalizer is not a moral sceptic, but merely critical concerning some of the features of morality that are responsible for the onerous demands imposed on her.

42 Moran (2012: 142) stresses that Kant did not only lecture about education, but was also an experienced educator himself. See also two letters from Kant to Marcus Herz sent in 1778 and 1789 (X:230.28-231.2, XI:48.26-32), as well as Munzel (1999: 283) for the relation between the philosopher and the educator. For recent discussions of Kant and education see Koch (2003), Louden (2011: ch.11), Moran (2012: ch.3), Munzel (2012), Roth and Surprenant (2012).

43 See also IV:405.2-5, V:151.9-12. See Sticker (2015) for a more extended discussion of the relation between common rational capacities and moral education.

44 This paper owes much to feedback from Jens Timmermann, Joe Saunders, Robert Stern, John Callanan, Tomas Land, Ashley Husband Powton and two anonymous referees. I am grateful to Kings College London for giving me the opportunity to present an earlier draft of this paper.

\section{Bibliography}

Citations to Kant's works are to the volume and page number of the "Akademie Ausgabe" of Kants gesammelte Schriften (Berlin: de Gruyter 1900-). Citations from the first Critique are given to the $\mathrm{A}$ and $\mathrm{B}$ editions. Translations from the Groundwork are from Timmermann (2011). Other works by Kant are quoted, with occasional modifications, from the Cambridge Edition of the Works of Immanuel Kant edited by Paul Guyer and Allan W. Wood.

Allison, H. (1990), Kant's Theory of Freedom. Cambridge: Cambridge University Press. Allison, H. (1998), 'Morality and Freedom: Kant's Reciprocity Thesis', in P. Guyer (ed.), Kant's Groundwork of the Metaphysics of Morals. Critical Essays. Lanham, Maryland: Rowman \& Littlefield.

Allison, H. (2004), Kant's Transcendental Idealism. An Interpretation and Defense. New Haven, London: Yale University Press.

Allison, H. (2011), Kant's Groundwork of the Metaphysics of Morals. A Commentary. Oxford: Oxford University Press. 


\section{Martin Sticker}

Allison, H. (2012), Essays on Kant. Oxford: Oxford University Press.

Ameriks, K. (2000), The Fate of Autonomy. Problems in the Appropriation of the Critical Philosophy. Cambridge: Cambridge University Press.

Ameriks, K. (2003), Interpreting Kant's Critiques. Oxford: Oxford University Press.

Ameriks, K. (2006), Kant and the Historical Turn. Philosophy as Critical Interpretation. Oxford: Oxford University Press.

Ameriks, K. (2010), 'Reality, Reason, and Religion in the Development of Kant's Ethics', in B. Lipscomb and J. Krueger (eds.), Kant's Moral Metaphysics. God, Freedom, and Immortality. Berlin, New York: De Gruyter.

Baxley, A. M. (2010), Kant's theory of virtue. The value of autocracy. Cambridge: Cambridge University Press.

Bittner, R. (1989), 'Das Unternehmen einer Grundlegung zur Metaphysik der Sitten. Zur Vorrede der Grundlegung', in O. Höffe (ed.), Grundlegung zur Metaphysike der Sitten. Ein kooperativer Komentar. Frankfurt a.M.: Vittorio Klostermann.

Chiba, K. (2012), Kants Ontologie Der Raumzeitlichen Wirklichkeit: Versuch Einer Anti-Realistischen Interpretation Der Kritik Der Reinen Vernunft. Berlin: De Gruyter. Deligiorgi, K. (2012), The Scope of Autonomy: Kant and the Morality of Freedom. Oxford: Oxford University Press.

Engstrom, S. (1997), 'Kant's Conception of Practical Wisdom', Kant-Studien 1/88:16-44.

Grenberg, J. (2009), 'The Phenomenological Failure of Groundwork III', Inquiry 4/52:335-356.

Grenberg, J. (2013), Kant's Defense of Common Moral Experience. A Phenomenological Account. Cambridge: Cambridge University Press.

Guyer, P. (1987), Kant and the claims of knowledge. Cambridge: Cambridge University Press.

Guyer, P. (2000), 'The Strategy of Kant's Groundwork', in P. Guyer (ed.), Kant on Freedom, Law, and Happiness. Cambridge: Cambridge University Press.

Guyer, P. (2003), 'Kant on Common Sense and Scepticism', Kantian Review 7:1-38.

Guyer, P. (2007), 'Naturalistic and Transcendental Moments in Kant's Moral Philosophy', Inquiry 5/50:444-464.

Guyer, P. (2009), 'Problems with freedom: Kant's argument in Groundwork III and its subsequent emendations', in J. Timmermann (ed.), Kant's Groundwork of the Metaphysics of Morals. A Critical Guide. Cambridge: Cambridge University Press. Henrich, D. (1998), 'The Deduction of the Moral Law: The Reasons for the Obscurity of the Final Section of Kant's Groundwork of the Metaphysics of Morals', in P. Guyer (ed.), Kant's Groundwork of the Metaphysics of Morals. Critical Essays, Lanham, Maryland: Rowman \& Littlefield.

Hill, T. Jr. (2012), Virtue, Rules, and Justice. Kantian Aspirations. Oxford: Oxford University Press. 
How can Common Rational Capacities Confirm the Correctness of the Deduction in Groundwork III-and Why does it Matter?

Kerstein, S. (2002), Kant's Search for the Supreme Principle of Morality. Cambridge: Cambridge University Press.

Koch, L. (2003), Kants ethische Didaktik. Würzburg: Ergon Verlag.

Korsgaard, C. (1996), Creating the Kingdom of Ends. Cambridge: Cambridge University Press.

Louden, R. (2011), Kant's Human Being. Essays on his Theory of Human Nature. Oxford: Oxford University Press.

Ludwig, B. (2008), 'Was wird in Kants Grundlegung eigentlich deduziert? Über einen Grund der vermeintlichen Dunkelheit des 'Dritten Abschnitts", Jabrbuch für Recht und Ethik 16:431-463.

McCarthy, M. H. (1982), 'Kant's Rejection of the Argument of Groundwork III', Kant-Studien 2/73:169-190.

McCarthy, M. H. (1985), 'The Objection of Circularity in Groundwork III', Kant-Studien 1/76:28-42.

Moran, K. (2012), Community and Progress in Kant's Moral Philosophy. Washington DC: Catholic University of America Press.

Munzel, F. (1999), Kant's Conception of Moral Character. The 'Critical' Link of Morality, Anthropology, and Reflective Judgement. Chicago: University of Chicago Press.

Munzel, F. (2012), Kant's conception of pedagogy. Toward education for freedom. Evanston: Northwestern University Press.

Nietzsche, F. (1980f), Die Fröbliche Wissenschaft, ed. G. Colli and M. Montinari. Berlin: De Gruyter.

Paton, H. J. (1946), The Categorical Imperative: A study in Kant's Moral Pbilosophy. London: Hutchinson's University Library.

Piper, A. (2008), Rationality and the Structure of the Self. Volume II: A Kantian Conception, http://www.adrianpiper.com/rss/index.shtml

Quarfood, M. (2006), 'The Circle and the Two Standpoints', in C. Horn and D. Schönecker (eds.), Groundwork for the Metaphysics of Morals. Berlin: De Gruyter. Roth, K. and Surprenant, C. (eds.) (2012), Kant and Education. Interpretations and Commentary. New York: Routledge.

Saunders, J. (2014), 'Kant, Rational Psychology and Practical Reason', Kant Yearbook. Schönecker, D. and Wood, A. (32007), Kants „Grundlegung zur Metaphysik der Sitten“. Ein einfübrender Kommentar. Paderborn: Schönigh.

Schönecker, D. (1997), 'Gemeine sittliche und philosphische Vernunfterkenntnis. Zum ersten Übergang in Kants Grundlegung', Kant-Studien 3/88:311-333.

Schönecker, D. (1999), Kant: Grundlegung III. Die Deduktion des kategorischen Imperativs. Freiburg, München: Alber.

Schönecker, D. (2006), 'How is a Categorical Imperative Possible?', in C. Horn and D. Schönecker (eds.), Groundwork for the Metaphysics of Morals. Berlin: De Gruyter.

Schönecker, D. (2009), 'The Transition from Common Rational Moral Knowledge to Philosophical Rational Moral Knowledge in the Groundwork', 


\section{Martin Sticker}

in K. Ameriks and O. Höffe (eds.), Kant's Moral and Legal Philosophy. Cambridge: Cambridge University Press.

Schönecker, D. (2013), 'Kant's Moral Intuitionism: The Fact of Reason and Moral Predispositions', Kant Studies Online. 1-38.

Stankovic, S. (2013), 'Kant's Deduction of Morality: The Actualization of Freedom', Kant Studies Online 45-71.

Stern, R. (2010), 'Moral Scepticism and Agency: Kant and Korsgaard', Ratio 4/23:453-474.

Sticker, M. and van Ackeren, M. (forthcoming), Kant and Moral Demandingness', Ethical Theory and Moral Practice.

Sticker, M. (2011), 'Warum die kantische Moralphilosophie der Bestätigung durch die gemeine Menschenvernunft bedarf', in XXII. Deutscher Kongress für Philosophie, http://epub.ub.uni-muenchen.de/12602/

Sticker, M. (2012), 'Legitimität und Grenzen moralischer Intuitionen bei Kant - Kant über gemeine Menschenvernunft und Vernünfteln', in A. Dunshirn, E. Nemeth and G. Unterthurner (eds.), Crossing Borders. Grenzen (über)denken. Thinking (across) Boundaries. Vienna: Phaidra.

Sticker, M. (2014), 'Jeanine Grenberg: Kant's Defense of Common Moral Experience. A Phenomenological Account, Kantian Review 2/19:315-318.

Sticker, M. (2015), 'Educating the Common Agent - Kant on the Varieties of Moral Education', Archiv für Geschichte der Philosophie.

Sussman, D. (2008), 'From Deduction to Deed: Kant's Grounding of the Moral Law', Kantian Review 1/13:52-81.

Tenenbaum, S. (2012), 'The Idea of Freedom and Moral Cognition in Groundwork III'. Pbilosophy and Phenomenological Research 3/84:555-589.

Timmermann, J. (2007), Kant's Groundwork of the Metaphysics of Morals. A Commentary. Cambridge: Cambridge University Press.

Timmermann, J. (2010), 'Reversal or retreat? Kant's deductions of freedom and morality', in A. Reath and J. Timmermann (eds.), Kant's Critique of Practical Reason. A Critical Guide. Cambridge: Cambridge University Press.

Timmermann, J. (2011), Immanuel Kant Groundwork of the Metaphysics of Morals. A German-English Edition. Cambridge: Cambridge University Press.

Thorpe, L. (2006), 'The Point of Studying Ethics According to Kant', The Journal of Value Inquiry 4/40:461-474.

Uleman, J. (2010), An Introduction to Kant's Moral Philosophy. Cambridge: Cambridge University Press.

Voeller, C. W. (2001), The Metaphysics of the Moral Law. Kant's Deduction of Freedom. Routledge: New York.

Wood, A. (2002), 'Preface and Introduction (3-16)', in O. Höffe (ed.), Immanuel Kant. Kritik der praktischen Vernunft. Berlin: Akademie Verlag. 